\title{
Memory Difficulties of Adult Patients with Shunted Hydrocephalus: A Clinical Study
}

\author{
Şant ile Tedavi Edilmiş Yetişkin Hidrosefali Hastalarında Hafiza \\ Kusurları: Bir Klinik Araştırma
}

Emel ERDOGAN BAKAR ${ }^{1}$, Bulent BAKAR ${ }^{2}$

${ }^{1}$ Ufuk University, Faculty of Medicine, Department of Psychology, Ankara, Turkey

${ }^{2}$ Kirikkale University, Faculty of Medicine, Department of Neurosurgery, Kirikkale, Turkey

Correspondence address: Bulent BAKAR / E-mail: bulentbanrs@yahoo.com

ABSTRACT

AIM: The purpose of this prospective study was to describe memory problems of adult patients with hydrocephalus.

MATERIAL and METHODS: The research group consisted of healthy adults (control group) and hydrocephlic adults (hydrocephalus group). The hydrocephalus group ( $\mathrm{n}: 19)$ had no clinical signs or symptoms of increased intracerebral pressure. The control group ( $\mathrm{n}: 20)$ was chosen from healthy adults. Both groups were evaluated by an experienced neuro-psychologist blinded to the groups. The examiner performed a battery of three different neuropsychological tests (Raven Standart Progressive Matrices, RSPM; Rey-Osterrieth Complex Figure Test, RCFT; and Rey Auditory-Verbal Learning Test, AVLT) to all groups.

RESULTS: Almost all subtest scores of the AVLT and RCFT remained significant after the RSPM scores were controlled. Almost all neuropsychological test results of the hydrocephalus group were significantly worse than control group.

CONCLUSION: This prospective study showed that adult patients with hydrocephalus have serious problems in memory function which might be directly caused by the hydrocephalus.

KEYWORDS: Adult, Hydrocephalus, Memory function

Öz

AMAÇ: Bu prospektif çalışma, şant ile tedavi edilmiş yetişkin hidrosefali hastalarının hafıza kusurlarını incelemek üzere oluşturulmuştur. YÖNTEM ve GEREÇ: Çalışmanın araştırma grubu sağlıklı yetişkinlerden (kontrol grubu; n: 19) ve klinik olarak artmış kafa içi basıncına ait semptom ve bulgusu olmayan hidrosefalik yetişkin hastalardan (hidrosefali grubu; n: 20) oluşturulmuştur. Her iki gruba, deneyimli bir nöropsikolog tarafından üç farklı nöropsikolojik testten oluşan bir test bataryası uygulanmıştır (Raven Standart Progressive Matrices, RSPM; ReyOsterrieth Complex Figure Test, RCFT; and Rey Auditory-Verbal Learning Test, AVLT).

BULGULAR: Hidrosefali grubu üyeleri tüm testlerde (zeka puanlarının da etkisi kontrol edildiği halde) kontrol grubuna kıyasla anlamlı düzeyde düşük puanlar almışlardır.

SONUÇ: Bu çalışma sonuçları şant ile tedavi edilmiş yetişkin hidrosefali hastalarının hafıza alanında belirgin sorunlar yaşadığını ortaya koymaktadır.

ANAHTAR SÖZCÜKLER: Yetişkin, Hidrosefali, Hafıza fonksiyonu

\section{INTRODUCTION}

An abnormal accumulation of cerebrospinal fluid (CSF) in the cerebral ventricular system known as hydrocephalus leads to increased intracranial pressure (ICP). Childhood hydrocephalus is associated with various cognitive deficits but the nature and course of the neuropsychological deficits in adult hydrocephalus are not fully understood. On the other hand some authors have indicated that although hydrocephalus is apparently arrested, the disorder may in fact progress insidiously in certain patients. In addition, continuous ICP monitoring demonstrates an increase in pressure in such patients (13). Some other studies in children have also showed that patients shunted previously with no neurological deficit show neuropsychological difficulties such as attention disorders, and memory difficulties; these difficulties may cause adaptive problems in social, cultural, behavioral and academic life $(1,2,6)$. Some of the cognitive dysfunction in hydrocephalic young adults with spina bifida are now being identified but their memory difficulties are poorly explained $(5,6,7,10)$. Donnet et al. (2004) concluded in their study that most neuropsychological difficulties of adult patients with aqueduct stenosis are related to fornix 
damage secondary to third ventricle enlargement and are related especially to immediate memory and planning, and consolidation of new information (3). In addition, Mataro et al. (2001) found that shunt placement improves the verbal and visual memory and attention of adult patients with spina bifida hydrocephalus (12). However, there are still only a few reports comparing the memory skills of hydrocephalic patient group whose disease is related to different aetiologies (11). The purpose of this prospective study was to describe memory problems of adult patients with hydrocephalus and without spina bifida.

\section{MATERIAL and METHODS}

\section{Subjects}

The research group consisted of healthy adults (control group) and hydrocephlic adults (hydrocephalus group). None of the patients had overt clinical signs or symptoms of increased intracerebral pressure.

The hydrocephalus group ( $\mathrm{n}: 19)$ contained 11 males (mean age, $37.03 \pm 8.07$ years) and 8 females (mean age, $36.11 \pm 12.15$ years) who were being followed-up with shunted hydrocephalus and had not underwent shunt revision in the last two years. The subjects were chosen from asymptomatic adults without motor and sensorineural deficit and subjects with neurological abnormalities (such as intracerebral or cerebellar tumour, intraventricular haemorrhage, epilepsy or stroke) were excluded from the study. This group was divided into two subgroups aetiologically: idiopathic aquaductal stenosis (n:11), and post-meningitis hydrocephalus $(n: 8)$. The patients with post-meningitis hydrocephalus who were treated had no infection parameter in the CSF sample. All subjects were statistically analyzed to determine the effect of the aetiological factors described above on all neuropsychological tests points by the Independent Sample $t$ Test and there was no statistically significant difference. This group was therefore not divided into its subgroups.

The control group ( $\mathrm{n}: 20)$ consisted of 11 males (mean age, $38.03 \pm 11.22$ years) and 9 females (mean age, 34.10 \pm 6.08 years) chosen from healthy adults.

The groups' sex and age distribution is shown at the Table I.

\section{Neuropsychological assessment}

All subjects underwent neuropsychological assessment that was administered in the same order by the same examiner.
They were evaluated by an experienced neuro-psychologist blinded to the groups. The examiner performed a battery of three different neuropsychological tests to all groups with routine procedures. These tests are identified below respectively:

1. Raven Standart Progressive Matrices (RSPM): The test originally produced by Raven et al. (1992) is accepted as a culture-fair test of general intelligence ( $\mathrm{g}$ factor) and also of visuospatial cognition ( $\mathrm{K}$ factor). RSPM performance requires working memory, category shift, mental flexibility, problem solving, abstraction and reasoning $(7,8,9)$.

2. Rey-Osterrieth Complex Figure Test (RCFT): This test is widely used to assess a number of cognitive processes including visual organizing ability, visual perceptual and constructional skills, planning, spatial ability, and visual-spatial memory (non-verbal memory) (4). RCFT consists of three steps - copy, immediate recall, and delayed recall - with a 30-minute delay between the second and third step. RCFT assesses 5 domains of neuropsychological functioning as following: visuospatial recall memory, visuospatial recognition memory, response bias, processing speed, and visual constructional ability (9).

3. Rey Auditory-Verbal Learning Test (AVLT): This test measures different aspects of verbal memory components such as immediate, delayed and free recall, learning rate, retroactive interference, and recognition in adults. In a more recent study, factor analysis produced factors depending on the combination of scores including "acquisition" and "retention". The latter was also subdivided into "storage" and "retrivial". The test consists of two common nouns list (AVLT-A and AVLT-B lists) which are read to participants, in 7 consecutive trials (Trials 1 through 7). Scores are calculated for the total number of words recalled over five trials, after interference, and the number of words recognized from the word list in a short story (recognition) $(10,17)$.

\section{Statistical Analysis}

The study results were normally distributed and the variation was homogenous between groups. Demographic data was investigated using the "Independent Sample t Test"; and p values less than 0.05 were considered to be significant. the "Analyses of Variance Test" (ANOVA) was used to investigate the effect of intelligence on test scores and $p$ values less than 0.05 were considered to be significant. Neuropsychological test points were analyzed with the "Multiple Analysis of

Table I: Descriptive Table of the Demographic Data of the All Group

\begin{tabular}{|l|c|c|c|c|r|r|}
\hline Group & Sex & N & Min & Max & Mean & Sd \\
\hline \multirow{2}{*}{ HYDROCEPHALUS } & Male & 11 & 26.09 & 52.09 & 37.03 & 8.07 \\
CONTROL & Female & 8 & 22.00 & 60.00 & 36.11 & 12.15 \\
& Male & 11 & 24.09 & 59.00 & 38.03 & 11.22 \\
& Female & 9 & 26.08 & 42.01 & 34.10 & 6.08 \\
\hline
\end{tabular}

(N: number of the patients; Min: minimum age; Max: maximum age; Mean: mean of age; SD: standard deviation) 
Covariance Test" (MANCOVA) and $p$ values less than 0.05 were considered to be significant. All data were analyzed using SPSS for Windows, release 15.0 (16).

\section{RESULTS}

Therewasnosignificant difference between the hydrocephalus and control groups for age, sex and aetiological factors (Independent Sample t Test, $\mathrm{p}>0.05$ ).

The effect of intelligence on test scores was investigated by using ANOVA; there was a significant difference between the groups in RSPM/ total score $(F=10.04 ; p=0.003)$ and RSPM/ duration $(F=23.30 ; p=0.000)$ (Table II, Figure 1).

Performances of the hydrocephalus and control groups on neuropsychological tests were compared by using MANCOVA, controlling for the effects of intelligence scores. Almost all subtest scores of the AVLT and RCFT remained significant after the IQ scores were controlled (Table III, Figure 2 and 3). There was no difference between RCFT/ recognition total subtest points ( $F: 0.96 ; p=0.334$ ).

The results showed that the hydrocephalus group had difficulties in short-term memory function which was measured by the AVLT/ A1 (F:17.19; p<0.001) and RCFT/ immediate recall subtests (F:57.70; $p<0.001)$. They also had difficulties in long-term memory function which was measured by the AVLT-trial $7(F: 26.35 ; p<0.001)$ and RCFTdelayed recall subtests (F:27.13; $p<0.001)$. They showed worse performance on learning ability as measured by AVLT/ A2 to A6. They also showed worse performance on recognition

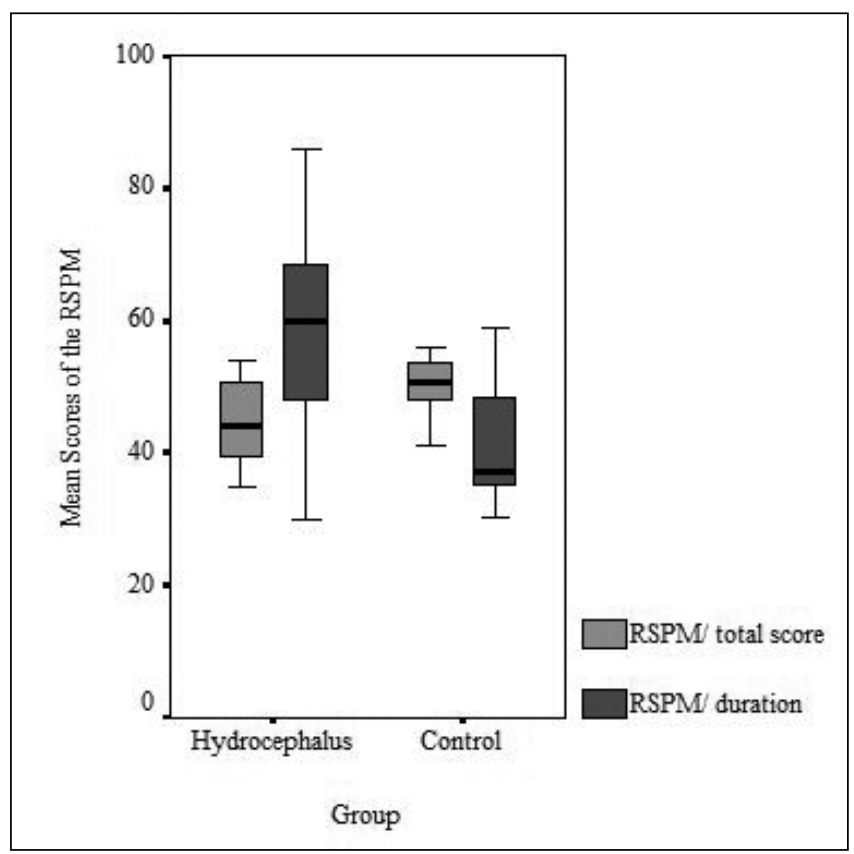

Figure 1: Mean values of the Raven Standart Progressive Matrices Test (RSPM)/ total correct and RSPM/ duration scores. Each error bar shows the minimum and maximum of the RSPM values. (RSPM: Raven Standard Progressive Matrices Test). ability that was measured by the $\mathrm{RCFT} /$ recognition-true ( $\mathrm{F}$ : 17.75, $p<0.001), A V L T /$ recognition $A(F: 25.43 ; p<0.001), A V L T /$ recognition $B(F: 27.66 ; p<0.001)$, and $A V L T /$ recognition $A B$ subtests (F:33.54; $\mathrm{p}<0.001)$.

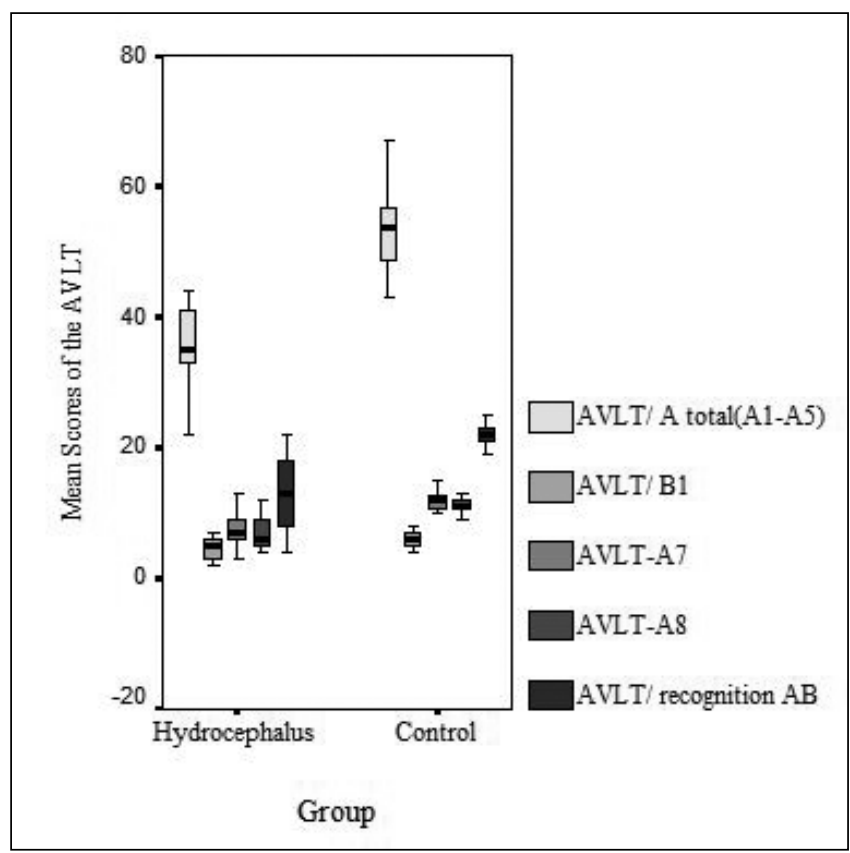

Figure 2: Mean scores of the Rey Auditory-Verbal Learning Test for subjects. Each error bar shows the minimum and maximum of the AVLT values. (AVLT: Rey Auditory-Verbal Learning Test).

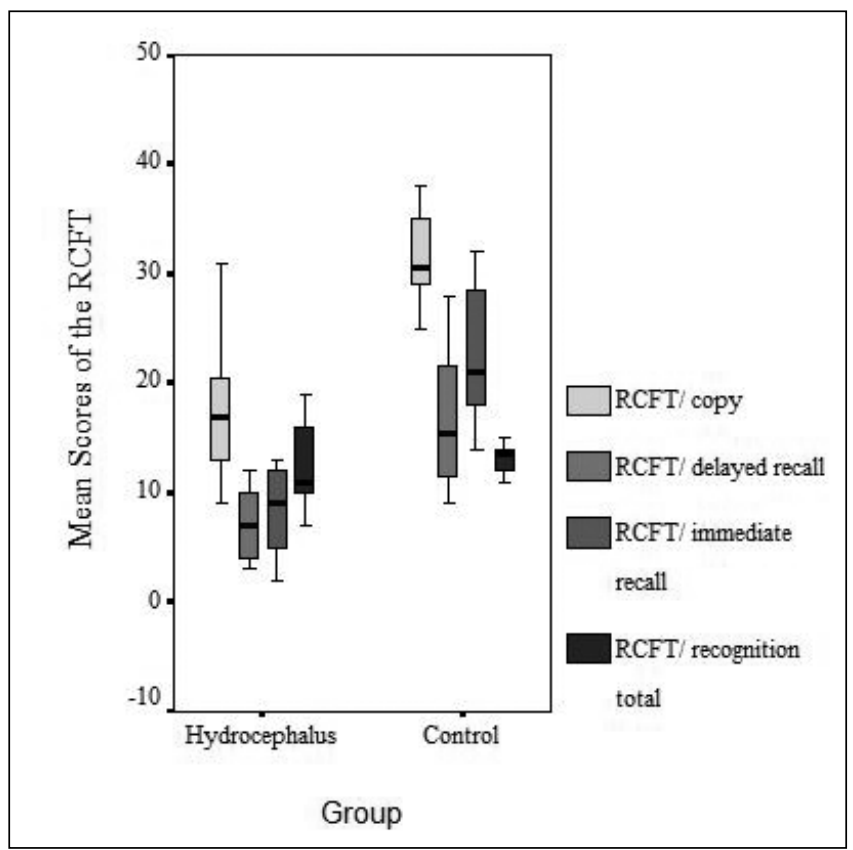

Figure 3: Mean scores of the Rey-Osterrieth Complex Figure Test for subjects. Each error bar shows the minimum and maximum of the RCFT values. (RCFT: Rey-Osterrieth Complex Figure Test) 
Table II: Comparison of the Hydrocephalus and Control Groups with Each Groups of RSPM Test Mean Scores, F, and p Values; Multiple Analysis of Covariance Test, $p<0.05$

\begin{tabular}{|c|c|c|c|c|}
\hline DEPENDENT VARIABLE & HYDROCEPHALUS & CONTROL & $\mathbf{F}$ & $\mathbf{p}$ \\
\hline \multicolumn{5}{|c|}{$\begin{array}{l}\text { Intelligence } \\
\text { Raven Standard Progressive Matrices (RSPM) }\end{array}$} \\
\hline RSPM/ total score & $44.11 \pm 7.86$ & $50.40 \pm 4.04$ & 10.04 & .003 \\
\hline RSPM/ duration & $60.42 \pm 15.75$ & $41.01 \pm 8.46$ & 23.30 & .000 \\
\hline
\end{tabular}

(F: measurement of distance between individual distribution; SD: standard deviation)

Table III: Comparison of the Hydrocephalus and Control Groups with Each Groups of AVLT and RCFT Test Mean Scores, F, and p Values; Multiple Analysis of Covariance Test, $\mathrm{p}<0.05$

\begin{tabular}{|c|c|c|c|c|}
\hline DEPENDENT VARIABLE & HYDROCEPHALUS & CONTROL & $\mathbf{F}$ & $\mathbf{p}$ \\
\hline \multicolumn{5}{|c|}{$\begin{array}{l}\text { Verbal memory } \\
\text { Rey Auditory-Verbal Learning Test (AVLT) }\end{array}$} \\
\hline AVLT-A1 & $5.58 \pm 1.98$ & $8.30 \pm 1.26$ & 17.19 & .000 \\
\hline AVLT-A2 & $6.53 \pm 2.17$ & $10.15 \pm 1.46$ & 23.33 & .000 \\
\hline AVLT-A3 & $7.32 \pm 1.86$ & $10.90 \pm 1.07$ & 38.11 & .000 \\
\hline AVLT-A4 & $8.21 \pm 1.87$ & $11.20 \pm 1.36$ & 21.02 & .000 \\
\hline AVLT-A5 & $8.95 \pm 2.17$ & $12.10 \pm 1.55$ & 16.33 & .000 \\
\hline AVLT-A1-A5 total & $36.63 \pm 9.28$ & $52.65 \pm 5.73$ & 27.28 & .000 \\
\hline AVLT-A7 & $7.58 \pm 2.57$ & $11.75 \pm 1.41$ & 26.35 & .000 \\
\hline AVLT-A8 & $7.00 \pm 2.29$ & $11.25 \pm 1.33$ & 33.09 & .000 \\
\hline AVLT/ recognition $A$ & $9.05 \pm 3.64$ & $14.15 \pm 1.14$ & 25.43 & .000 \\
\hline AVLT/ recognition B & $3.79 \pm 2.46$ & $8.10 \pm 1.59$ & 27.66 & .000 \\
\hline AVLT/ recognition $A B$ & $12.84 \pm 5.72$ & $22.25 \pm 1.80$ & 33.54 & .000 \\
\hline \multicolumn{5}{|c|}{$\begin{array}{l}\text { Non-verbal memory } \\
\text { Rey-Osterrieth Complex Figure Test (RCFT) }\end{array}$} \\
\hline RCFT/ copy & $17.37 \pm 6.22$ & $31.60 \pm 3.87$ & 49.95 & .000 \\
\hline RCFT/ immediate recall & $8.47 \pm 3.75$ & $22.75 \pm 5.66$ & 57.70 & .000 \\
\hline RCFT/ delayed recall & $7.00 \pm 2.96$ & $16.45 \pm 5.70$ & 27.13 & .000 \\
\hline RCFT/ recognition-true & $8.42 \pm 2.14$ & $10.65 \pm 1.04$ & 17.75 & .000 \\
\hline RCFT/ recognition-false & $3.95 \pm 2.27$ & $2.45 \pm 1.23$ & 4.71 & .037 \\
\hline RCFT/ recognition-total & $12.47 \pm 3.60$ & $13.10 \pm 1.74$ & 0.96 & .334 \\
\hline
\end{tabular}

(F: measurement of distance between individual distribution; SD: standard deviation)

\section{DISCUSSION}

Recent literature has shown that raised ICP can produce mechanical stress and impaired cerebral metabolism by decreasing cerebral blood flow $(2,6)$. This cerebral dysfunction may also cause some difficulties regarding memory, attention and executive function in children with hydrocephalus $(1,15)$. Donnet et al. (2004) suggested that memory impairment in hydrocephalus with aqueductal stenosis could be correlated with enlargement of the third ventricle that interrelates with the fornices, hippocampus, mamillary bodies, and enlargement of the lateral ventricles that interrelates with the basal forebrain, anterior temporal cortex, and parietal-occipital cortex. The anterior temporal cortex is considered essential for long-term memory storage, with the right temporal lobe (non-dominant hemisphere of the brain) mediating nonverbal learning and memory, and the left temporal lobe (dominant hemisphere of the brain) mediating verbal learning and memory in most individuals (3). Our study supported this theory as hydrocephalic adults showed worse performance on verbal and non-verbal memory. Our results therefore disclosed that hydrocephalic adults showed low performance levels on immediate recall, delayed recall, free recall, learning rate, retroactive interference, and recognition skills located on the dominant cerebral hemisphere. They also showed 
poor performance on visual perceptual and constructional skills, planning, spatial ability, and visual-spatial memory located on the non-dominant hemisphere. Using these results, we may speculate that these patients have difficulties with the organization of short-term and long-term memory, learning, and recognition skills. On the other hand, Mataro et al. (2001) found no significant difference between patients with active versus compensated hydrocephalus in their study. However, they found an association between the magnitude of the ventricular dilatation and verbal and visual memory and suggested that larger ventricles could be associated with poor performance on verbal and visual memory, and less improvement after surgery in a cued recall task. They also found after shunt surgery that the neuropyschological test results were better than the preoperative results but still worse than the control group $(12,13)$. Although our study has not contained preoperative neuropsychological or morphological assessment of hydrocephalic patients, the results of our study compared with healthy control group results confirm the findings of Mataro et al. (2001). Actually, we can speculate that the shunt surgery could not improve the memory to the same level as the control group. We also agree with these authors that more studies are required to resolve the pathophysiology and management of the hydrocephalus. Furthermore, we think that the effectiveness of the shunt surgery and third ventriculostomy on the memory function of the hydrocephalic patients should be evaluated and also compared in future studies.

Most research on patients with hydrocephalus has focused on patients with spina bifida because of its homogeneity. In this study we included patients with aqueductal stenosis and post-infectious hydrocephalus. The aetiology of adult hydrocephalus in this study was heterogeneous, suggesting that the consequences were of hydrocephalus per se, with its influence on white and gray matter structures. In our study, statistical analyses performed on demographic data showed that the aetiology of the hydrocephalus, age, sex and localization of the shunt (frontal or posterior parietal) did not affect the test results, as reported in the literature (1, $6,11)$. We can therefore suggest that these difficulties may be caused by hydrocephalus itself and not the aetiological factors. That means deficits on the short-term and long-term memory function may arise from the ventricular dilatation which may destruct the metabolism and function of both hemispheres of the brain. Our study highlights the need to determine the effects of developmental anomalies on memory by comparison of memory difficulties of patients with spina bifida-hydrocephalus and aqueduct stenosishydrocephalus. Overall, this study also highlights the need to evaluate and describe the memory difficulties and psychiatric problems of hydrocephalic adults by using more specific neuropsychological tests in future investigations.

\section{CONCLUSION}

This prospective study showed that patients with hydrocephalus have difficulties regarding the organization of short-term and long-term memory, learning, and recognition skills that might be directly caused by the hydrocephalus; and these problems may cause serious adaptive difficulties in their social, cultural, behavioral and academic life.

\section{REFERENCES}

1. Bakar EE, Bakar B, Taner Yl, Akalan N: Evaluation of the intellectual skill problems of hydrocephalic children: A clinical study. Turk Neurosurg 19: 29-35, 2009

2. Del Bigio MR: Hydrocephalus-induced changes in the composition of cerebrospinal fluid. Neurosurgery 25: 416-423, 1989

3. Donnet A, Schmitt A, Dufour H, Giorgi R, Grisoli F: Differential patterns of cognitive impairment in patients with aqueductal stenosis and normal pressure hydrocephalus. Acta Neurochir (Wien) 146: 1301-1308, 2004

4. Frazier TW, Adams NL, Strauss ME, Redline S: Comparability of the Rey and Mack forms of the Complex Figure Test. Clin Neuropsychol 15: 337-344, 2001

5. Hetherington R, Dennis M, Barnes M, Drake J, Gentili F: Functional outcome in young adults with spina bifida and hydrocephalus. Childs Nerv Syst 22: 117-124, 2006

6. Hommet C, Billard C, Gillet P, Barthez MA, Lourmiere JM, Santini JJ, de Toffol B, Corcia P, Autret A: Neuropsychologic and adaptive functioning in adolescents and young adults shunted for congenital hydrocephalus. J Child Neurol 14: 144-150, 1999

7. Iddon JL, Morgan DJ, Loveday C, Sahakian BJ, Pickard JD: Neuropsychological profile of young adults with spina bifida with or without hydrocephalus. J Neurol Neurosurg Psychiatry 75: 1112-1118, 2004

8. Karakaş S: Bilnot Bataryası El Kitabı: Nöropsikolojik Testler İçin Araştırma ve Geliştirme Çalışmaları. 2. baskı. Ankara: Eryılamaz Ofset, 2006

9. Koppitz EM: The Visual Digit Span Test. New York: Grune and Stratton, 1977

10. Lezak MD: Neuropsychological assessment. Ed 3. New York: Oxford University Press, 1995

11. Lindquist B, Persson EK, Uvebrant P, Carlsson G: Learning, memory and executive functions in children with hydrocephalus. Acta Paediatr 97: 596-601, 2008

12. Mataró $M$, Junqué $C$, Poca $M A$, Sahuquillo J: Neuropsychological findings in congenital and acquired childhood hydrocephalus. Neuropsychology Review 11: 169-178, 2001

13. Mataró M, Poca MA, Sahuquillo J, Cuxart A, Iborra J, de la Calzada MD, Junqué C: Cognitive changes after cerebrospinal fluid shunting in young adults with spina bifida and assumed arrested hydrocephalus. J Neurol Neurosurg Psychiatry 68: 615-621, 2000

14. Raven JC, Court JH, Raven J: Manual for Raven's standard progressive matrices. Oxford: Oxford Psychologists Press, 1992

15. Rourke BP: Nonverbal learning disabilities: The syndrome and the model. New York: Guilford Press, 1989

16. SPSS Inc. SPSS base 13.0 for Window's user guide. Chicago: SPSS Inc., 2004

17. Vakil E, Blachstein H: Rey Auditory-Verbal Learning Test: structure analysis. J Clin Psychol 49: 883-890, 1993 